\title{
Review \\ Relationships between brothers of children with disabilities. Some educational psychology considerations.
}

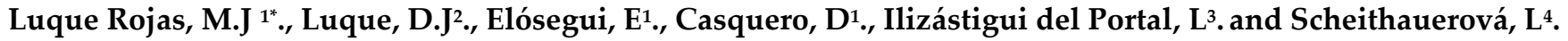

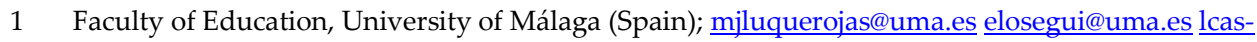
quero@uma.es

2 Faculty of Psychology and Speech Therapy, University of Málaga. (Spain); dluque@uma.es

3 Faculty of Psychology, University Santo Tomás (Chile); lilizastigui@santotomas.cl

4 Faculty of Education, Charles University. Prague (Czech Republic). lenka.scheith@gmail.com

* Correspondence: mjluquerojas@uma.es

\begin{abstract}
The existence and family living with a sibling with a disability implies a dynamic and a structure with meaning to children and their circumstances. However, a sibling that accompanies, helps, or takes part in family life, usually is lower analysis compared with children with disabilities. The goal of this work is to analyze the behavior of children before siblings with disabilities. Following two children's opinions in this context. It is intended to make some analysis about the children's behavior towards their sibling, and finally, seek reflection on the structure of family relationships.
\end{abstract}

Keywords: Family. Disability. Relationships.

\section{Introduction}

The family structure and organization is altered with the birth of a new sibling, and a new atmosphere of relationships and affections must re-emerge among its members so that a renewed bond of intimacy and affective relationship is established. This will mark each of the members in their identity references, as well as in the aspects of social interaction [1]. The new feelings will form a nucleus that will permeate relationships and will mark the explanations and coping mechanisms of the new situation.

This family balance, and its regulatory mechanisms, acquire greater complexity if a child has a disability, and this could be due, as stated in [2], to two aspects:

- A psychological assessment that has appreciated the affective relationships between siblings from a vision focused on the negative aspects of jealousy, rivalry, or envy (leaving other aspects such as help, affection, play, company, or solidarity).

- Consideration of the disability from the focus on the person who has it and their parents, being rare that it deals with the experience of coexistence of the siblings, their responses, and personal approaches.

In this sense, as has been shown in some publications, there have been more studies focused on the mother and the implication of having a child with a disability, almost totally excluding parents, extended family, and siblings [3]; [4], not valuing the weaknesses and strengths or positive aspects in the development of the sibling's personality.

Without entering into opinions of the various authors on the subject [5] [6] [7] [8] [9] [10] only to highlight the disparity of opinions regarding the psychological adjustment of the brother without disabilities, compared to the brother who has disabilities. Thus, from a psychological perspective (call it classic or pathogenic), difficulties emerge, maintaining a pathological view in children who have a sibling with a disability. On the other extreme, from positive psychology, disability would not be a stressor in itself, being able to speak 
of advantages or experiences in values [1]. Without positioning ourselves in one extreme or the other, we would consider reflecting on a position of assessment and acceptance of the situation, as well as the path of life in which an affectivity and experiences, both positive about the disability, and about negative and stressful experiences and emotions [11] [7].

In this affective development, according to the aforementioned, the characteristics of the family, the specific needs of the sibling with a disability, as well as the appropriate and permanent reflection on the emotional adjustment and personal development of all children should be considered. As has already been expressed [12], it would not be about the existence of the brother with a disability, nor about the disability itself, but the adjustment of the structure of family relationships, as well as affective development and staff of all children, with timely attention to each one of them, according to their needs, which implies not focusing on the child with a disability. The siblings each have their place and circumstance, having to work on relationships, acceptance, and adaptation. In this way, the brother without disabilities will be able to think, express himself and get answers to his questions about the brother with some limitation, so that the emotions or negative experiences when expressing them, stop having a depth charge, to be able to become experiences of personal development, with a perspective of values and attitudes.

This work aims to analyze the behavior of children before a sibling who has a disability, following the opinions of two children in that situation. From the evaluation of their ideas and feelings, we would seek to favor reflection on the structure of family relationships that, without a doubt, in the circumstances of disability of one of its members can be altered, and, consequently, suggest proposals for action in the acceptance and adaptation to the situation, both at the family level and in the Tutorial Action in the classroom and educational center.

Note that this is not to assume that having a sibling with a disability is a family tragedy in any way. On the contrary, it is sought to assume that this circumstance entails assimilation and acceptance so that, overcoming uncertainties and generating personal and family growth, the framework of affective relationships that any person and social group need for their better development and progress is established. It is evident that Education, the educational system, and Educational Guidance have something to say.

\section{Two cases of illustration}

Jesús (assumed name) is an 8-year-old boy who has a sister with an intellectual disability. Since he entered the educational center, he has manifested behavior of relative restlessness and inattention, as well as a lower performance than is supposed for his capacity, according to the observations of the family and the teaching staff. In the same way, his expressions of unease and thoughts aloud about the condition of his sister with disabilities and her relationship with her have been appreciated. The request for psychological intervention is justified by that family observation of some behaviors with a marked affective accent (seriousness or sadness, certain anxious-depressive aspects), associated with concern for his sister with a disability, as well as the possibility of a feeling loss. To this are added behaviors with a lower degree of attention-concentration and restlessness, which could affect his school performance.

In this aspect, it can be seen how the student feels responsible for helping in the care of her sister, not hiding her uneasiness about her behavior, nor the frustration due to the limitation that it entails in her normal activities. However, he accepts the difficulties in his relationship with his sister and with her parents, believing that her needs acquire a certain value, which must be considered to carry out family life.

His medical history is not significant, and it can be said that he has a healthy child history. The nuclear family is made up of the three brothers, their father, and mother, observing an affective structure of good relationships, as well as a correct balance between the occupation and the concern of the parents towards their children. The aspect that acquires relevance is that his middle sister has a disability (West syndrome), a circumstance 
that not only has not altered that structure but has also reinforced it in a positive attitude in the parents and theirs towards their children.

The student, when asked about this family situation, expresses some concern, expressing a certain negative feeling towards his sister (as he says: more attention is paid to her and I must always give in), but at the same time, it is observed that puts those feelings, his thoughts, actions, and emotions in favor of his sister. The attitude of the child does not hide us from certain anger towards her sister for conditioning her life, which leads to a later feeling of guilt for those thoughts. In this case [1], the child's experience concerning the family situation can be made clear, an experience that can explain the child's behaviors and manifestations of an anxious-depressive type, less interest, as well as thoughts about his role towards her sister, responsibility towards her, how will her future social or affective relationships, ... These affective-emotional aspects have been able to influence her person, as well as her learning and academic performance, having to intervene with the family, advising in the structure of affective relationships and, in short, providing attention to the demands of the child, from a framework of normality, with less incidence in anxiety or worry and seeking the expression and promotion of emotion and feelings, with assumption and control.

Angela is a 12-year-old girl who has twin brothers with an autism spectrum disorder. With a difference of about six years to them, she becomes aware of the difficulties of her siblings, when around the age of five (hers), she notices that children maintain a distance in their relationship with her and their parents, serving as a comparison his peers in Early Childhood Education. Angela does not show negative behaviors of particular interest in this situation, but she does appreciate that they do not interact like other children, that they do not indicate what they like or do not like, or that they do not come to play. She feels that her parents spend almost all the time dedicated to them and that they ask her to help them at times.

At school, the girl shows a behavior that is little less than exemplary, with excellent academic performance and exemplary personal - social behavior. In this sense, the request for psychological intervention is only justified by a presumption of the teacher who, aware of the family circumstance, wants in some way to take care of the student. It is true that having no apparent behavioral manifestations if he has expressed to his teacher any concern about the behaviors of his brothers, which make him present an attitude of sadness or a feeling of what to do, or of a hope that they can improve (to get well) or even what will happen when they are older.

The student, when asked about her family situation, with the distance of age and her good intellectual level, responds with a certain mood of sadness, which she overcomes by the affection to her little brothers and by the necessary help to her parents, she explains everything as we are a family, and we must help each other. She assumes that her siblings demand a lot of attention and that she understands it, but as the girl would say, my parents are also very aware of me and take care of me, but I am a little older, I am fine, and I can handle myself. Like Jesus, she puts her feelings and actions before her siblings. On occasion, she has expressed some concern that her siblings could determine her times and activities, which will undoubtedly make her feel bad for having those thoughts.

In both cases, a balanced structure of affective relationships in the family is appreciated, as well as a vision of the disability of the siblings, positive, affectionate, and with attitudes of acceptance, support, and from beliefs of progress in their personal and social evolution. To this are added some individual characteristics of high intellectual capacity and affective development within a framework of values of collaboration (not providing help due to paternal or maternal imposition), care, acceptance, and respect, for being a family. This perhaps represents the nucleus that feeds the good family relationships of children with disabilities, insofar as, from a young age, siblings without limitation learn to live their circumstances, to live with their brother with difficulty, in an assumption of natural luck of situation. Something that can be destabilized as soon as you compare with other families or friends, hence the importance of an adequate father, mother and children relationship, as well as the constant reflection on family coexistence and, in short, 
permanent attention on the balance between occupation and concern for the family structure and the development of their children.

Thus, according to some authors [8] [13] [14] [12] [2], these two students could participate in a set of opinions, thoughts, and feelings, common to boys and girls who have siblings in this circumstance of disability (Table 1).

Table 1. Common thoughts and feelings of siblings of children with disabilities.

I feel that my parents do not treat me fairly, concerning my sibling with a disability.

I have learned many things from my disabled brother/sister.

My parents always defend or protect my brother/sister with a disability more.

If it had not been for my brother with a disability, I would not have recognized values and respect for all people.

My parents do not inform me of my brother's things. I feel isolated.

I behave well, I am studious because I want my parents to be happy, they already have enough with the concern of my brother/sister with a disability.

I feel happy when my parents go to the movies, go out for a walk, to have dinner, ...

Sometimes I feel lonely as if my parents love my brother more and me less.

I would like them to show me more than they love me.

I feel bad if my brother can't do things like me.

I feel ashamed or sorry when we go out and meet him.

I wish I knew more about what my brother has.

I think about what I will do and how I will take care of my brother/sister when my parents are gone.

More rules and more demands apply to me than to my brother/sister.

Thanks to my brother with a disability, I can put myself in the place of people with difficulties and understand them.

He has taught me that I should value more what I have and not just what I don't do well.

I have learned to be more patient or considerate of people with some limitations.

I feel obliged to help my brother, my parents demand it of me.

He has taught me to be stronger in difficulties.

I believe that the whole of society should think and work more with those who have difficulties or need help.

In the cases of these two students, for these categories of the table, both in the boy and in the girl, there is a general assessment of their reflection on the family situation, around positive thoughts or values that, globally could be summarized as:

- Learn from their brothers or sister in their situation, as well as recognize some values and respect for other people. 
- Study or behave well so that their parents are happy, in return for the concern of their sister or brothers.

- Learn to know more about his brother's disability and how he can help better.

- Value the aspects of patience, recognize what they have (how lucky they are to be healthy), the strength in difficulties, and in what way make the whole of society think and work more with those who have difficulties or need help.

On the other hand, there are also some other less positive thoughts or feelings, such as:

- Sometimes I wonder if my parents treat me fairly because they always defend or protect my sibling with disabilities more.

- I feel isolated or alone; it is as if my parents love my sibling more and me less. Yes, I know it is not true but sometimes I think about it.

- I do not know what others will think when we go out and meet them and this worries me; I would like to know what to do.

It should be stated that the previous thoughts or feelings of both children are less important than the previous positive ones, which is probably explained by the family structure in which the circumstances derived from the sister, or brothers, have been addressed by the parents from a perspective of acceptance and co-responsibility among the members, transferring and assuming the roles that they have had to live. In this way, they can achieve an organized family dynamic (functions and activities), individual development of each of the members, and a projection in their contexts tending to normalization.

It is obvious to express that the observations of the concrete cases do not deal with representativeness or normative framework, but rather with the consideration of two aspects. On the one hand, that siblings of children with special educational needs are also special since they have experienced feelings and thoughts that are difficult for other children to understand and that will continue to accompany their sibling throughout life. On the other hand, that in the diversity of families and situations, there is a need to intervene from the educational psychology area and contribute to the improvement of the affective development of boys and girls, as well as family balance and emotional support to parents.

\section{Considerable aspects of the family structure}

In the cases discussed and starting from their normal development, as well as a recognized sensitivity in both participating children a certain level of unease or emotional involvement in each of their family situations. Expressions that, when observed and treated by parents, as well as at school, provide the opportunity for their knowledge and, consequently, allow the family to work, in one hand, on the promotion of feelings and emotions, from a base of personal and social enrichment, and in the other hand, in the emotional expression that gives way to the understanding of what is felt, shaping the depth of the sensitivity and channeling its intensity. Undoubtedly, these actions bring together the needs of students in terms of their personal development, as in their unique relationship with their brothers or sister with disabilities.

Their assessment of good intellectual capacity provides, of course, an indisputable cognitive basis with which to affirm the possibility of adequate processing in the 
explanations or analysis of family situations and with the sister or brothers. But, at the same time, it allows showing the dissonance between the affective and the cognitive, with the convenient need for action in the emotional sphere, something that is typical in boys and girls with high intellectual capacities [15]. In this aspect, it can be seen how the two students feel responsible for helping in the care of their siblings, not hiding their concern or unease about their behaviors or the frustration due to the possible limitation that it entails in their normal activities. Despite this, they accept the difficulties of their relationship with their sister or brothers and with their parents, believing that their needs acquire a certain value that must be considered to carry out family life. Something that, being so young, can already be called co-responsibility and that will mark their future of personal and social development, with accredited values in their exercise.

Another aspect of interest is the fact of thinking about your situation to your brother. Both children experience in some way the presence and characteristics of their sister or brothers, certainly appreciating their limitations and, at the same time, trying to explain the needs of their brother, as well as the possibilities of the relationship with him. This involves an exercise in putting yourself in the shoes of your disabled brothers or sister, which entails:

- Assess the aspects that make up this disability and what impact they have on the personal life of each of the family members-

- Enter into acceptance of the circumstance of disability.

- Adopt vital approaches in adaptation to the situations [2].

Certainly, these children are aware of the limitations of their siblings, so it is obvious to think that they assume their disability or specific needs. Daily, they observe, participate, help or collaborate in the activities to be done with that sibling, leading him to reflect, both in the circumstances of his brothers, as in those of his relationship with himself and with his future himself [12]. Their thoughts about the behavior of their siblings, as well as the attitude of their parents (differentiation in their dealings with children), can generate concern about what he or she does and is expected to do, which will surely result in feelings of restlessness and unease, probably different and distant from their peers, but also of responsibility and obligation that deserve to be addressed by parents and professionals, towards goals of understanding, support, and consideration.

The approach of parents and teachers - tutors in the center, according to [14], [15] should be:

- Avoid, or at least neutralize, feelings such as being an older brother who must permanently take care of his sister or brothers.

-Provide that the girl, due to the fact of being the girl (gender bias), has no more restrictions and obligations than those of her age and her possibilities in the family structure.

- Avoid that the boy or the girl feels the obligation alone to face this family dynamic.

- Appreciate that the disability of her sister or brothers is supervening, so they should not feel responsible for that disability, nor for the possible sadness of her parents about her.

- Expressing anger towards a sibling with a disability for whatever reason is something natural in family life and should not feel guilty for having these thoughts. 
- Work on the fact that the existence of their sister or brothers with disabilities can cut back, to a certain extent, their social life, outings, or leisure activities. Sometimes the resignation or selection of friends based on how they react to the sibling with a disability is a filter for better social relationships.

- They are not obliged to make up for the hopes and expectations (of their parents) that their brother will not be able to achieve.

In short, favoring in these children a hopeful vision of the development of their siblings, which will surely come from a tight balance between occupation and concern in relationships and actions with their brother or sister. Without a doubt, brotherly love will prevail by clearing up uncertainties and pointing out solutions.

From a psychoeducational and pedagogical perspective, the needs posed by these children, in terms of their affective development and behavioral aspects, must be recognized, so that the teachers intervene within a tutorial action, knowing all the aspects, both positive and negative, of the disability of the brother, identifying the student's needs, proposing coping strategies, assessing the positive of having that brother and ultimately favoring his enrichment as a person.

\section{Some considerations in families}

Considering that personal construction occurs within a collective culture, which organizes the internal worlds and interpersonal relationships, it is possible to express the existence of family and social contexts, which are favorable and unfavorable to personal construction. In the case of families with children with disabilities, the necessary assumption and overcoming of this circumstance by the parents must be considered, as well as the importance of an adequate structure of affective relationships, all for personal development in the children. In this sense, an attempt will be made to neutralize attitudes with negative emotional development (sadness, hopelessness, and restlessness, ...), aiming to assess the differences between siblings with or without disabilities, referring to their characteristics, framed in the development of values and attitudes with personal and social progress in their lives.

Family dynamics by themselves are always about coping, especially due to the existence of a sibling with specific needs, which is assumed from the development of values and attitudes in collaboration and responsibility, in help and acceptance, typical of a framework of paternal - filial and fraternal love. From this perspective, parents should be encouraged to develop these values, so that they generate a structure of relationships with their children in which differential actions with each of them (distributive justice), allow to neutralize negative feelings and attitudes or overprotection, implementing effective care and support strategies and behaviors.

It is unnecessary to express the impact of disability on family structure and dynamics, so we will not consider the various common aspects in families and the siblings of children with disabilities (see in this regard [14]; [16] [13] [12]). However, we could express the positive aspects that favor personal and social development and growth in the siblings (Table 2). 
Table 2. Aspects that favor personal and social growth in the siblings.

\begin{tabular}{l}
\hline Empathy \\
\hline Affection and defense of those who need it \\
\hline Eagerness for protection and support \\
\hline Sense of social justice \\
\hline Tolerance, acceptance, and respect towards the difference \\
\hline Coexistence and accompaniment of parents in the feeling of relationship with the brother \\
\hline Feeling of competence and increased self-esteem, due to increased responsibility in caring for \\
the brother \\
\hline Personal strength and joy in the face of any advancement of the brother with a disability \\
\hline Development of prosocial behavior and greater sensitivity and positive attitudes towards \\
people with disabilities \\
\hline Opportunity for social learning and coping strategies, reducing difficulties in adjusting to \\
stress in adult life \\
\hline Compassion, awareness of help, and collaboration between siblings, reinforcing family ties \\
\hline Knowing how to listen, be supportive, and adaptability \\
experiences, differentiated from those of their parents \\
Exne
\end{tabular}

Experience in active and proactive cognitive, behavioral and interpersonal coping strategies.

The union and common goals that characterize a family can only be achieved if all its members have feelings of belonging and shared affection. Feelings that arise from affection and defense, from protection and help, from tolerance and acceptance, from coexistence and the accompaniment of parents in the relationship with the brother with difficulties and family life. In these families of siblings with disabilities, a feeling of competence and increased self-esteem are learned and developed, due to the fact of responsibility in caring for the sibling, as well as personal strength and joy in the face of any progress made by the sibling with a disability. Undoubtedly, compassion, awareness of help, and collaboration between siblings reinforce family ties, but also knowing how to listen, be supportive, and the ability to adapt. All learning involves the development of prosocial behavior and greater sensitivity and positive attitudes towards people with disabilities, as well as social learning and coping strategies, reducing difficulties in adjusting to stress in adult life.

In the network of relationships and their affective reciprocity, the triangulation of father - mother - children, with the circumstance of children with special needs, is formed as a nucleus of action-reflection without a solution of continuity in its exercise, but guided by considerations of values and attitudes, moved by a feeling of belonging and filial and fraternal love and with the purpose of personal, social and moral development in the children.

\section{Some considerations for the Tutorial and Teaching Action}


In any educational community, all teachers are called to meet parents, to advise and train them, to understand and collaborate. In the same way, specialists in Psychology, Pedagogy, or Educational Psychology, in their intervention with families and teachers with students with disabilities, should take care and concern themselves more with an enabling action than a rehabilitation one, with the development of capacities and personal and social growth, besides of the curricular and adjustment of the teaching-learning. A professional-family relationship model is therefore established, which takes into account family aspects, but also contextual ones, that the interests and needs of parents are appreciated, as well as the expert opinion of professionals. That is, to advocate for a negotiation model [17] in which a balance is sought between center-family, professionals-parents, working in collaboration, shared activities in the experience, and mutual recognition.

In an educational environment (institutional - school), teaching action must be understood from the positive of personal and social growth, generating an active climate of respect for the dignity of other people and acceptance, tolerance, solidarity, and cooperation. Consequently, any educational intervention in the affective-emotional sphere of the students makes sense, especially when the teachers are involved in a Tutorial Action that deals with the individual characteristics and interpersonal relationships of their students, not only from the circumstantial coexistence of the classroom or center but in active and affective interaction, according to values and norms, with the objectives of a positive coexistence and personal and social development of all students.

Consideration of a set of elements of educational activity that has as elements for reflection may be deemed necessary: On the one hand, on the importance of the family relationship and between siblings, in coexistence with a disability and, on the other, the actions themselves favor attitudes in the student and promote their better adaptation to their circumstances. It is obvious to express that it will be the teaching staff who structures and plans, depending on their needs and curricular approaches, their tutorial action.

Any educational action on personal development in the classroom, gravitates on the conception of a Tutorial Action, as an interactive circumstance person - context, focused on the personal and dealing with areas of affective and social integration. The educational context is ideal to generate empathy and positive feelings, as well as the understanding of individual differences and needs, to foster helpful and cooperative attitudes, promoting them from schoolwork and coexistence.

In the Tutorial Action, the teachers will take care to encourage in their classroom, behaviors in which the interpersonal relationships of their students predominate, not only from the circumstantial coexistence of the classroom or center but also in the active and affective interaction, according to some values and norms, with the objective of a positive coexistence and personal and social development of all students. Teaching action must be understood from the positive of personal and social growth, generating an active climate of respect for the dignity of other people and acceptance, tolerance, solidarity, and cooperation. The teacher will convey to parents the convenience of maintaining a social or community life, going out and enjoying their children (including the disabled child), without qualms about what people may think, thus generating vision standards and, consequently, a greater likelihood that these people will be understanding.

From this purpose in the Tutorial Action, some of the following can be indicated as concrete objectives.

In the teaching staff: 
- Promote democratic attitudes of acceptance and respect for rights and values, particularly those of people with disabilities. Develop consistent behaviors, about what you try to teach your students.

- Foster a classroom climate of cooperation and help, friendship, and acceptance of differences.

- Develop attitudes and skills for discussion, group tasks, assertive behaviors, and emotional expression.

In the students:

- Know the positive aspects and needs of support and resources of people with disabilities.

- Acquire knowledge and feeling about oneself, concerning the situation of these people.

- Develop knowledge and specific skills in dealing with people with disabilities.

Regarding the specific situation of siblings with disabilities, the following could be taken into account as general aspects in the intervention in the classroom (Table 3)

Table 3. General aspects for an intervention in the classroom.

\begin{tabular}{ll}
\hline \multicolumn{1}{c}{ General objectives } & \multicolumn{1}{c}{ Activities framework } \\
\hline $\begin{array}{l}\text { A) Generate structure and social relations in } \\
\text { which equality prevails among all, } \\
\text { eliminating prejudices about people with } \\
\text { disabilities, developing organized } \\
\text { relationships towards favorable attitudes of } \\
\text { acceptance and spontaneous help. }\end{array}$ & $\begin{array}{l}\text { - Cooperative tasks and general attitudes, in } \\
\text { which the disabled student is competent, } \\
\text { favoring a positive and natural dynamic of } \\
\text { relationships. }\end{array}$ \\
$\begin{array}{l}\text { B) Encourage the characteristics of children } \\
\text { with disabilities to be valued in their people } \\
\text { and circumstances, reducing previous ideas, } \\
\text { stereotypes, or erroneous beliefs in other } \\
\text { students (and teachers), who frequently use } \\
\text { the part for the whole. }\end{array}$ & $\begin{array}{l}\text { furniture, help in preparing the subject... } \\
\text { playground, favoring situations of friendship } \\
\text { and affection, necessary to maintain a climate } \\
\text { of equality and naturalness in the school }\end{array}$ \\
& $\begin{array}{l}\text { context. } \\
\end{array}$
\end{tabular}

Teachers must be aware that, situated in a family context with children with disabilities, putting themselves in the place of a boy or girl, brother of another with some limitation, implies accepting the circumstance of the disability, assessing the aspects that make it up and that have an impact on the personal life of each of the family members, adopting vital approaches adapted to the situations. Following this, it is situated in a framework conducive to the development of sensitivity towards disadvantaged people, awareness and responsibility in helping, accepting, or supporting the person with a disability and assessing it as a situation or circumstance, in them that we are all participants in its improvement or accessibility [18].

\section{Conclusions}

We are located in an Inclusive School, in which disability is not seen as a problem, but rather as an object of solutions, moreover, of satisfaction of needs, without being based 
on the deficiency, or the emphasis on the difficulty or limitations due to disorders or alteration. A School that recognizes the personal and social development of children, as the nucleus of progress, which entails their acceptance as a person, the understanding of their characteristics, and the adjustment of their educational response. Its corollary is that the difficulties or limitations arise from a lack of accessibility or understanding of the situations and in this, the responsibility lies with the entire community.

In a sense and scope of a collaboration of sharing, schools must be for families, places of reception, and centers of psychosocial and educational attention, in which, as inclusive educational environments, integration in the community and society is working, being all its participating members and facilitators of the accessibility and support conditions. In the reciprocal interaction family and community, there is a coming and going of influences, through which the development of both the children and the parents takes place, these considered not only promoters of the development of their children but also as subjects in personal and social growth. Consequently, the community can intervene in the family as a whole, thus favoring security, recognition, trust, acceptance, and the feeling of belonging and coexistence, avoiding exclusion and sharing values and beliefs of a democratic and supportive community. Considering disability in the light of these values, the school is and must be, the appropriate instance for this intervention and development of the person, being the best way of transmission and coexistence.

\begin{abstract}
Author Contributions: Conceptualization, Luque-Rojas; M.J., Luque, D.; methodology, Luque-Rojas; M.J., and Elósegui, E.; formal analysis, Luque-Rojas; M.J., Elósegui, E. and Luque, D.; investigation, Luque-Rojas; M.J. and Luque, D.; resources, Luque-Rojas; M.J. and Luque, D.; writing-original draft preparation, Luque-Rojas; M.J. Luque, D. and Casquero, L.; writing-review and editing, Luque-Rojas; M.J. Luque, D. Scheithauerová, L. and Casquero, L.; visualization, Luque-Rojas; M.J., Luque, D. and Ilizástigui, L.; Validation, Luque-Rojas; M.J. Luque, D. and Ilizástigui, L.; supervision, Luque-Rojas; M.J. and Luque, D.; project administration, Luque-Rojas; M.J. and Luque, D.; funding acquisition, Luque-Rojas; M.J. and Luque, D. All authors have read and agreed to the published version of the manuscript."
\end{abstract}

Funding: This research received no external funding.

Acknowledgments: We are grateful to children and families who participated in this analysis study.

Conflicts of Interest: The authors declare no conflict of interest.

\title{
References
}

1. Luque-Rojas, M. J. (2020). Pautas de intervención familiar en hermanos de niños con discapacidad. In Claves para la innovación pedagógica ante los nuevos retos: respuestas en la vanguardia de la práctica educativa, López-Meneses, E., Cobos-Sanchiz, D., Molina-García, L., Jaén-Martínez, A. and Martín-Padilla, A.H. Octaedro: Barcelona, Spain, 2020; pp. 30-38.

2. Luque, D. J. and Luque-Rojas, M. J. (2020). My brother has a disability. I am also here. Polyphōnia. 2020, 4(2), 199-216.

3. Stoneman, Z. and Gavidia-Payne, S. Marital Adjustment in Families of Young Children with Disabilities: Associations with Daily Hasslesand Problem-Focused Coping. American journal on mental retardation, 2006, 111(1), 1-14.

4. Moreno, C. Revisión teórica sobre el ajuste psicológico y emocional de los hermanos de personas con discapacidad intelectual. Revista Española sobre Discapacidad Intelectual, 2010, 41(3), 235, 60 - 78.

5. Cuskelly, M., and Gunn, P. Adjustment of children who have a sibling with Down syndrome: Perspectives of mothers, fathers, and children. Journal of Intellectual Disability Research, 2006, 50(12), 917-925.

6. Dew, A., Balandin, S., \& Llewellyn, G. The psychosocial impact on siblings of people with lifelong physical disability: A review of the literature. Journal of Developmental and Physical disabilities, 2008, 20(5), 485-507.

7. Iriarte, C. and Ibarrola-García, S. Revisión de estudios sobre la vivencia emocional de la discapacidad intelectual por parte de los hermanos. Estudios sobre educación, 2010, 19, 53-75.

8. García Núñez, Roberto, Bustos Silva, Guillermina. Discapacidad y problemática familiar. Paakat: Revista de Tecnología y Sociedad [Internet]. 2015; (8): Recovered from: https://www.redalyc.org/articulo.oa?id=499051499005

9. Muñoz Bravo, J. (2017). Informe. Hermanos/as adultos de personas con discapacidad intelectual o del desarrollo: revisión de datos comparativos España-EE. UU. Plena Inclusión España: Madrid, Spain.

10. Oñate, L. and Calvete, E. Una aproximación cualitativa a los factores de resiliencia en familiares de personas con discapacidad intelectual en España. Psychosocial Intervention, 2017, 26(2), 93-101. 
11. Núñez, B. A. and Rodríguez, L. Los hermanos de las personas con discapacidad: Una asignatura pendiente. Buenos Aires. Ed. AMAR. 2005.

12. Luque-Rojas, M. J., Matas, A., Luque, D. J. (2019). Hermanos de niños con discapacidad. Elementos para la reflexión. AIDIPE. Proceedings of XIX Congreso Internacional de Investigación Educativa: Investigación Comprometida para la Transformación Social. Madrid, Spain. June 2019.

13. Núñez, B. A., Rodríguez, L. and Lanciano, S. El vínculo fraterno cuando uno de los hermanos tiene discapacidad. Revista Española sobre Discapacidad Intelectual. 36(4), 2005, 216, 50 - 74.

14. Lizasoáin, O. Impacto que puede conllevar tener un hermano con discapacidad: factores condicionantes y pautas de intervención. Siglo Cero, 38(223), 2007, 69-88.

15. Luque, D. J., Luque-Rojas, M. J. y Hernández, R. (2019). Desarrollo afectivo y necesidades específicas de apoyo educativo en el alumnado con altas capacidades intelectuales. Revista AOSMA, 25, 2019, 14-22.

16. Lizasoáin, O., González, M. C., Iriarte, C., Peralta, F., Sobrino, A., y Onieva, C. E. Hermanos de personas con discapacidad intelectual: Guía para el análisis de necesidades y propuestas de apoyo. Estudios sobre educación, 22, 2011, $221-247$.

17. Paniagua, G. Las familias de niños con necesidades educativas especiales. In Marchesi, A.; Coll, C. and Palacios, J. (Eds.). Desarrollo psicológico y Educación. 3. Trastornos del desarrollo y necesidades educativas especiales. Madrid. Alianza. 1999.

18. Luque-Parra, D.J. and Luque-Rojas, M.J. Actitudes de solidaridad y aceptación hacia el alumnado con discapacidad. Revista de Educación Inclusiva, 5(2), 2012, 25-41. 